Revista Cógnito v.2:1 (2020) 30 - 48

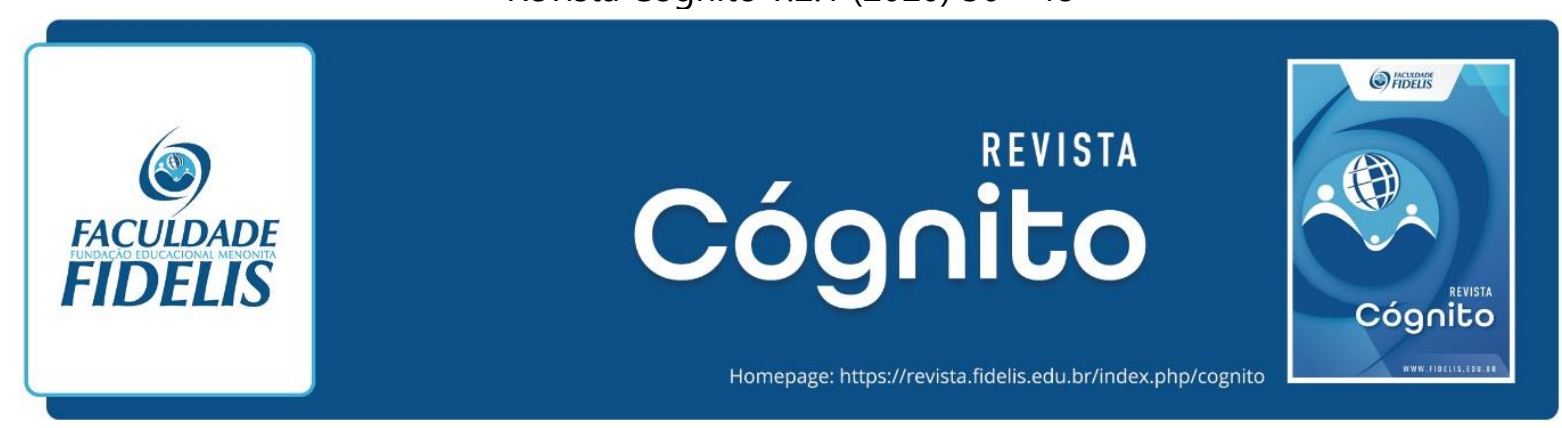

\title{
MORAL: UMA PROVA DA EXISTÊNCIA DE DEUS PARA AS NAÇÕES E SUAS IMPLICAÇÕES MISSIOLÓGICAS
}

\author{
MORAL: A PROOF OF GOD'S EXISTENCE TO NATIONS AND ITS \\ IMPLICATIONS IN MISSIONS
}

\author{
Jürgen Harder ${ }^{1}$ \\ Arthur Wesley Dück ${ }^{2}$
}

\section{RESUMO}

Este trabalho visa estudar o que a Bíblia diz sobre uma moral intrínseca nas pessoas não cristãs, como uma forma de revelação geral de Deus e suas implicações missiológicas. Segundo a pesquisa bibliográfica, a Bíblia aponta para um moral entre os seres humanos que se origina na Criação do mundo, podendo ser vista na ordem da Criação e na Imagem e Semelhança de Deus no homem, além disso uma antecedência comum dos seres humanos em Noé também aponta para esta moral. Na figura de Jesus Cristo o exemplo moral perfeito é revelado por Deus para os seres humanos. Paulo mostra em Romanos que a revelação geral aponta para Deus através dos atributos invisíveis e lei escrita no coração, mas não é salvífica. Assim o objetivo do trabalho e mostrar que a moral de uma pessoa aponta para Deus e pode ser usada para estabelecer um ponto de contato com o não cristão, para trazer o evangelho.

PALAVRAS-CHAVE: Moral. Ponto de contato. Imagem de Deus. Leis de Noé. Atributos Invisíveis. Lei escrita no coração. Revelação Geral. Tao de Lewis.

\section{ABSTRACT}

This article aims to study what the Bible says about an inner moral in non-Christian people as a form of the general revelation of God and its missiological implications. According to bibliographical research, the Bible points to a moral among humans that was originated in the Creation of the world, and can be seen in the order of Creation and in the image and likeness of God in the man, and besides that, a common antecedent of the human race coming from Noah also points to this moral. In the figure of Jesus Christ, the perfect moral example is revealed from God to the human kind. Paul shows in Romans that the general revelation points to God

\footnotetext{
${ }^{1}$ Discente do curso de Bacharelado em Teologia da Faculdade Fidelis. jurgenharder@yahoo.com.br.

2 Doutor em Teologia pela Escola Superior de Teologia - EST. Docente do curso de Bacharelado em Teologia da Faculdade Fidelis. arthurwduck318@gmail.com.
} 
through invisible attributes and the law written on the heart, but it is not salvific. Therefore, the purpose of the article is to show that a person's morals points to God and can be used to establish a point of contact with non-Christians to bring the gospel.

KEYWORDS: Moral. Contact point. God's image. Noah's Laws. Invisible Attributes. Law written on the heart. General Revelation. Tao of Lewis.

\title{
INTRODUÇÃO
}

\author{
Quando a terra ainda era jovem, \\ E ainda carregava as claras pegadas de Deus, \\ As pessoas queriam ser sábias e eternas como Ele; \\ E antes delas tentarem, \\ Se sentiam fortes o suficiente, \\ Porém para onde isso levava, \\ Elas apenas perceberam mais tarde!
}

Nessa estrofe da música Es geht ohne Gott in die Dunkelheit (O caminho sem Deus leva à escuridão) ${ }^{3}$ do compositor alemão Manfred Siebald (1948-) é descrito o momento da rebelião dos personagens bíblicos Adão e Eva e a consequente "queda" de toda a humanidade ao caírem na tentação de quererem ser iguais a Deus, de acordo com o texto bíblico de Gênesis 3. Mas, essa estrofe de Siebald tem nas suas duas primeiras linhas algo muito interessante, "quando a terra ainda era jovem, e ainda carregava as claras pegadas de Deus", ou seja, havia pegadas de Deus na natureza, que mostravam o seu criador ou apontavam para ele. Mesmo conhecendo e vendo estas "pegadas" os primeiros seres humanos se rebelaram contra Deus e as consequências se refletem na história da humanidade. Mas é possível ver "pegadas" de Deus ainda hoje? O que seriam estas "pegadas"?

Don Richardson afirma que as "pegadas" de Deus ainda podem ser encontradas nas mais diversas nações e culturas, o que defende em seus livros "Totem da Paz" (2016) e "Fator Melquisedeque" (2008). Esta também é a opinião de Alister McGrath em "Teologia Natural” (2019) e C. S. Lewis em “Cristianismo Puro e Simples” (2017) e "Abolição do Homem” (2017). Richardson mostra como diversos povos apresentam manifestações, entendimento e questões culturais que apontam para Deus de forma semelhante aos registros bíblicos, e como isso pôde ser usado como um fundamento para construir a mensagem do evangelho para esses povos. A Teologia Natural tem sido interpretada de várias formas ao longo da história, por isso McGrath

\footnotetext{
${ }^{3}$ Tradução nossa.
} 
a reconstrói para dar um entendimento correto e mais apropriado a ela para que se torne realmente relevante para a fé cristã. McGrath (2019) mostra que Deus deixou "pegadas" para a humanidade na natureza, na perfeição da criação e na moral ${ }^{4}$ dos seres humanos. Lewis (2017) de certa forma também segue a linha da moral, e defende a ideia de que as mais diversas nações têm uma espécie de código moral comum, o que ele chama de Tao.

A Bíblia relata que o homem foi criado à imagem e semelhança de Deus (Gn 1.27). Após a Queda (Gn 3), a humanidade resolveu fazer suas próprias escolhas morais e seguir um caminho sem Deus. Será que a imagem e semelhança de Deus com base na qual o homem foi criado, de acordo com Gênesis 1.27, ainda continua a lhe dar consciência do certo e do errado e apontar para seu Criador? Será que os primeiros capítulos de Romanos se referem à moral como uma das qualidades invisíveis de Deus para a humanidade e como uma lei escrita no coração das pessoas? Através disso, é possível para qualquer pessoa vir a conhecer Deus?

A Hipótese: É possível afirmar que todas as pessoas têm uma noção de moral, do certo e do errado, além disso, "eles mostram pela sua maneira de agir, que têm a lei escrita no coração. A própria consciência deles mostra que isso é verdade, e os seus pensamentos que às vezes os acusam e às vezes os defendem, também mostram isso" $\left(\mathrm{Rm} 2.14,15\right.$. $\left.\mathrm{NTLH}^{5}\right)$. Isso as torna indesculpáveis perante Deus, e pode ser usada como uma ponte para que o evangelho chegue ao coração das pessoas.

Ao entrar em contato com pessoas não cristãs percebe-se que muitas delas buscam fazer o bem e ajudar os necessitados. Buscam a justiça e o amor e lutam por causas de forma altruísta. Segundo Romanos 1 e 2, todas as pessoas, de certa forma, sabem da existência de Deus. A moral é parte da revelação geral de Deus e quando uma pessoa que não segue os ensinamentos da Bíblia faz uma boa ação por puro altruísmo está mostrando que tem uma noção do bem e do mal. Isso mostra a imagem e semelhança a Deus nela, e com isso é possível fazer uma ponte para falar do amor de Jesus para essa pessoa.

O objetivo deste estudo é identificar a possível existência de uma verdade moral ou moral universal com base na Bíblia, que pode ser vista em todas as pessoas, inclusive as que não se denominam cristãs, podendo ser usada como uma ponte para falar de Jesus Cristo a elas.

\footnotetext{
${ }^{4}$ Moral: "Conjunto de valores e princípios morais (virtude, honestidade etc.) que norteiam a conduta e o pensamento de uma pessoa e sua relação com a sociedade em que vive". Disponível em: https://michaelis.uol.com.br/moderno-portugues/busca/portugues-brasileiro/moral/ acesso em 25 de novembro de 2019.

${ }^{5}$ Todas as citações bíblicas do trabalho são retiradas da Bíblia Nova Tradução da Linguagem de Hoje exceto quando o uso outra tradução é especificada.
} 
Nesse estudo, pretendeu-se verificar o que os dois primeiros capítulos de Romanos ensinam sobre a moral e suas raízes desde a Criação, principalmente a moral entre os povos não cristãos; identificar a moral como parte da imagem e semelhança de Deus nos homens, intrínseca ao ser humano; compreender se a Revelação Geral de Deus inclui também a moral; verificar como a ideia de uma moral universal de Deus pode ser usada para dialogar com os que ainda não creem em Jesus e usá-la como fundamento para levar o evangelho para eles.

\section{CRIAÇÃO - A PERFEITA MORAL DE DEUS PARA AS NAÇÕES}

"E Deus viu tudo o que havia feito, e tudo havia ficado muito bom" (Gn 1.31). Assim se encerra o relato da criação no final do sexto dia em Gênesis 1, o que pressupõe segundo McGrath (2005, p. 353) que a Criação de Deus é essencialmente boa e tudo o que Deus havia feito era perfeito.

Huntemann (1983, p. 37-39) diz que essa ordem na Criação foi dada pela Palavra de Deus. Pela Palavra a terra foi criada, pelo comando da Palavra a criação sempre é mantida em ordem. Assim a questão ética e moral também faz parte deste equilíbrio da ordem da criação. A Palavra de Deus como moral significa dar proteção, conservação e significado à criação. A Palavra que comanda e a Palavra que cria são a mesma. Assim por exemplo: o mandamento que diz "você não deve dar falso testemunho" traz a verdade para o mundo corrompido pela mentira. As leis de Deus são a luta para trazer o mundo caído em pecado novamente à ordem, a luta da Luz contra as Trevas, a luta do ser contra a não existência niilista. Assim Deus traz os seus mandamentos para a criação para estabelecer a ordem, "quem vive contra o Mandamento, vive contra a criação, pois o Mandamento ou Lei são a Ordem da criação" (HUNTEMANN, 1983, p. 38).

Para aquelas pessoas que não creem na Bíblia, nem na existência de Deus, argumentos baseados nela não têm valor. Desta forma, usar argumentos bíblicos para a apologética cristã não ajuda no diálogo com não cristãos. Porém, alguns argumentos tradicionais os levam à reflexão. Um destes argumentos que defende existência de um Deus e consequentemente de um Deus criador é o argumento moral. Este argumento "parte do senso humano do certo e do errado, e da necessidade da imposição da justiça, e raciocina que deve necessariamente existir um Deus que seja a fonte do certo e do errado e que vá algum dia impor a justiça a todas as pessoas" (GRUDEM, 1999, p. 99).

Não só a ordem da criação remete a uma moral. Gênesis 1.26,27 relata que o homem foi criado à imagem e semelhança de Deus e a moral também está atrelada a isto: "Então disse 
Deus: "Façamos o homem à nossa imagem, conforme a nossa semelhança [...]. Criou Deus o homem à sua imagem, à imagem de Deus o criou; homem e mulher os criou" (NVI) ${ }^{6}$. Para Sturz (2012, p. 294-299) esta semelhança e imagem de Deus não significa necessariamente igualdade, mas similaridade. Assim, o ser humano, antes da Queda tem esses aspectos similares da natureza essencial de Deus. De certa forma, esta é a moral na criação, mas Sturz lista mais alguns atributos que são semelhantes às características do homem, como bondade, misericórdia, justiça e até ira. (STURZ, 2012, p. 294-302).

Para os primeiros leitores ou ouvintes de Gênesis, o significado de ser criado à imagem e semelhança de Deus era claro. Não era necessário explicar que isto envolvia aspectos da “capacidade intelectual, pureza moral, natureza espiritual, domínio sobre a terra, criatividade de tomar decisões éticas e imortalidade", o próprio desenrolar das Escrituras explicava estes aspectos. Porém, com a Queda ${ }^{7}$ esta imagem passa a ficar distorcida, "sua pureza moral se perdeu, e seu caráter pecaminoso certamente não espelha a santidade de Deus", assim como também o seu intelecto ficou corrompido pelo engano e seus relacionamentos pelo egoísmo (GRUDEM, 1999, p. 365-366).

Os aspectos morais da criação do ser humano à imagem e semelhança de Deus segundo Grudem são explicados do seguinte modo:

(1) Somos criaturas moralmente responsáveis pelos nossos atos perante Deus. Correspondente a essa responsabilidade, temos (2) um senso íntimo de certo e errado que nos separa dos animais (que têm pouco ou nenhum senso inato de moralidade ou justiça, mas simplesmente reagem ao medo do castigo ou à esperança da recompensa). Quando agimos segundo os parâmetros morais divinos, nossa semelhança a Deus se espelha numa (3) conduta santa e justa perante ele, mas, por outro lado, nossa dessemelhança a Deus se revela sempre que pecamos. (GRUDEM, 1999, p. 367).

McGrath (2019, p. 187) escreve em relação a imago dei de Gênesis 1.26,27, que "ao longo de sua extensa análise desse texto fundante, a igreja cristã veio a entendê-la como indicação de que há algo intrínseco à natureza humana que lhe permite identificar, ainda que de forma um pouco vaga, o caráter de Deus na ordem criada".

O fato de a humanidade ser criada à imagem de Deus é, em grande parte, considerado como o fator responsável pela virtude e dignidade originais da natureza humana". Para Lactantius, ${ }^{8}$ o fato de o homem ser criado a imagem e semelhança de Deus fez com que de certa forma, as nações tivessem uma identidade e dignidade comum, e em

\footnotetext{
${ }^{6} \mathrm{NVI}$ : Bíblia na Nova Versão Internacional.

${ }^{7}$ Queda é o que a Bíblia descreve como sendo o ato de rebelião da humanidade contra o seu Criador, descrito no livro de Gênesis 3, considerado o momento que o pecado/mal entra no mundo.

8 Lucio Célio Firmiano Lactâncio (240-320 d.C) foi um autor e apologeta entre os primeiros cristãos que se tornou um conselheiro do primeiro imperador romano cristão, Constantino I. Disponível em <https://www.britannica.com/biography/Lactantius> acesso em 22 de novembro de 2019.
} 
consequências deveres e direitos humanos iguais. Por causa da Queda do homem, a imagem de Deus na humanidade, em sua natureza humana, ficou distorcida, assim toda ela sofre dos problemas desta descaracterização da imagem de Deus. Com isso, “entende-se que a queda de Adão afeta o caráter moral do ser humano. Todas as deficiências morais do ser humano, inclusive luxúria e a ganância, podem ser atribuídas ao pecado de Adão (McGRATH, 2005, p. 504).

Assim, de certa forma a imagem de Deus está presente no ser humano, "quer ele reconheça a existência e a obra de Deus, quer não". Essa característica intrínseca não se perdeu com a Queda e é inerentemente parte do ser humano, mesmo que de forma opaca e distorcida. Assim, ela está presente tanto em pessoas cristãs como não cristãs. A universalidade desta imagem de Deus confere dignidade aos homens e por isso "existem atos de bondade praticados por pessoas não cristãs, não meritórios no que diz respeito à busca do favor divino para a salvação, mas agradáveis a Deus por contribuírem para seu propósito geral”. Desta forma a imagem de Deus nas pessoas as torna sensíveis às coisas espirituais, muitas vezes de forma encoberta. Este é um canal potencial de receptividade ou acessibilidade para as pessoas buscarem a comunhão com Deus, pois a imagem de Deus dentro delas clama por isso e estarão incompletas se não experimentarem (ERICKSON, 2015, p. 502).

Depois da Queda, a Bíblia relata em Gênesis 4 a 6 como a humanidade se desvia do plano de Deus e cai cada vez mais em depravação moral e pecado. Apesar de ainda serem feitos à imagem e semelhança de Deus, "a história demonstra claramente que humanos agora, depois da Queda no pecado, têm capacidade terrível de descaminhar sua vida". Aquilo que Deus havia criado perfeito, as boas dádivas de Deus, acabam sendo desvirtuadas pelos seres humanos. Assassinato, inveja, ira, depravação sexual, vingança e violência fazem parte da vida da humanidade depois da Queda. Mas Deus não desistiu do seu plano, assim ele vê em Noé, o único homem reto e moral uma chance para recomeçar, sendo Noé uma espécie de "novo Adão" (BARTHOLOMEW; GOHEEN, 2017, p. 56-59).

Segundo Sturz (2012, p. 356), "Deus viu que, nos dias de Noé, toda inclinação do coração humano "era sempre e somente para o mal" (Gn 6.5). Por conseguinte, salvou Noé e sua família, mas destruiu o restante da humanidade. A arca, porém, "carregou com seus passageiros a natureza adâmica decaída”. Apesar disso, a imagem de Deus não foi totalmente apagada. Após o Dilúvio em Genesis 9, a pena capital é instituída naquilo que a tradição judaica chama de "as sete leis de Noé", para remeter a humanidade para aquilo o qual foram criados, a imagem e semelhança de Deus.

Assim, o fato do ser humano ser criado à imagem de Deus traz consigo toda questão da moral, pois mesmo depois da Queda, quando Deus estabelece uma aliança com Noé (ver 
capítulo 2 deste trabalho), ela é mencionada em Genesis 9.6. "Quem derramar sangue do homem, pelo homem seu sangue será derramado, porque à imagem de Deus foi o homem criado". "Embora o texto não declare explicitamente -que os seres humanos ainda portavam a imagem de Deus, fica evidente que o realizado anteriormente por Deus ainda estava em vigor ou tinha algum efeito, mesmo após a Queda" (ERICKSON, 2015, p. 487).

Na narrativa bíblica da Criação, a moral pode ser vista de forma intrínseca. A ordem criada por Deus concede ao mundo um perfeito equilíbrio, no qual a moral também faz parte. A lei de Deus mantém a ordem na criação. Além da ordem que remete a uma moral, a criação do homem a Imagem e Semelhança de Deus também dá pistas de uma moral comum aos seres humanos. Essa Imagem de Deus faz com que o homem acabe refletindo atributos do próprio Deus, e mesmo ao se afastar Dele depois da Queda, a lei moral ainda atua no ser humano, impedindo a sua depravação total.

\section{LEIS DE NOÉ - A HERANÇA MORAL PARA AS NAÇÕES}

"Segundo a tradição judaica, Deus havia concedido sete leis a Noé, leis pelas quais toda a humanidade era responsável" (KEENER, 2017, p. 510).

Lewis (2017, p. 80-81) defende a ideia de que todas as nações ou civilizações tenham uma origem comum, e possuem um senso moral comum, o que ele denomina de $\operatorname{Ta}^{9}$. Essa origem comum segundo a Bíblia é a família de Noé, da qual todas as nações descendem após o dilúvio: "Deus disse a Noé: Vou mandar um dilúvio para cobrir a terra, a fim de destruir tudo o que tem vida; tudo o que há na terra morrerá. Mas com você eu vou fazer uma aliança. Portanto, entre na barca e leve com você a sua mulher, os seus filhos e as suas noras" (Gn 6.17,18). Depois do Diluvio, Deus novamente diz para Noé: “Tenham muitos filhos, e que os seus descendentes se espalhem por toda a terra" (Gn 9.1).

Nesse Tao, várias civilizações antigas e modernas são citadas e o que estas dizem a respeito de temas como a benevolência ou bondade, deveres para com a família, lei da justiça, compromisso com a veracidade ou lei da boa-fé, lei da misericórdia e magnanimidade. Lewis (2017, p. 80-81) mostra que nas mais diversas áreas, muitas civilizações no mundo apresentam uma similaridade, o que não pode ser fruto do acaso, mas sim, comprova a sua origem em

\footnotetext{
${ }^{9}$ Tao: Termo que C. S. Lewis usa para definir e englobar o conjunto de princípios morais de civilizações, culturas e filosofias que mesmo fora do cristianismo também possuem influência da chamada Lei da Natureza Humana ou Lei da Moral, segundo a filosofia. Este Tao Lewis (2017) trabalha em Abolição do Homem, ao rejeitar o niilismo da sua época e defender o conhecimento moral.
} 
comum. Nota-se que este Tao, possui aspectos muito semelhantes com o que a tradição judaica chama de sete leis de Noé: não praticar idolatria, não blasfemar contra Deus, não cometer homicídio, não roubar, não cometer adultério e não manter relações incestuosas, estabelecer tribunais e não molestar os animais ingerindo um órgão retirado em vida. ${ }^{10}$

Segundo a tradição, estas sete leis foram dadas a Noé e sua família logo após o Dilúvio para funcionarem como base moral para toda a humanidade que descenderia desta família, para que funcionasse como sua base. ${ }^{11}$

\begin{abstract}
No âmago deste código moral universal está o reconhecimento de que a moralidade na verdade, a própria civilização - deve ser baseada na crença em Deus. A menos que reconheçamos um Poder Mais Alto perante quem somos responsáveis, e que observa e conhece as nossas ações, não transcenderemos o egoísmo de nosso caráter e a subjetividade de nosso intelecto. Se o próprio homem é o árbitro do certo e errado, então o "certo" para ele será aquilo que deseja, independentemente das consequências para os outros habitantes da terra. ${ }^{12}$
\end{abstract}

A tradição judaica explica essas sete leis como princípios básicos da fé, ética e moral universais e se fossem seguidos por todas as nações poderia haver uma existência pacífica e justa entre elas. Mas vai mais além ainda e diz que essas leis podem ser vistas nos mais diversos povos. As sete leis da aliança noaica se assemelham bastante com as leis de Moisés segundo Pate (2015, p. 35).

Ao discutirem em Atos 15, sobre o quanto da Lei os gentios convertidos deviam seguir, os apóstolos chegaram ao consenso de que deviam seguir basicamente quatro pontos: abster-se de comida contaminada pela idolatria, se abster da imoralidade sexual e se abster da carne de animais estrangulados e do sangue (At 15.20). Ao usarem essas recomendações para os novos convertidos, os apóstolos estavam usando ou reinterpretando as regras básicas para estrangeiros residentes entre os judeus que eram baseada nas leis de Noé. As leis parecem ser uma versão da "lei natural", um reconhecimento de que todo ser humano que faz uso da razão pode concordar com um grupo de leis que asseguram a justiça e uma sociedade ordenada. Ao contrário das leis para o estrangeiro residente, esta formulação não contém nenhum requisito ritual. Assim essas leis consistiam em um código moral mínimo para que os gentios recebessem as recompensas de Deus (RAMBO, FAHRADIAN, 2014, p. 590-591).

\footnotetext{
10 Disponível em: <https://pt.chabad.org/library/article_cdo/aid/3312135/jewish/As-Sete-Leis-deNo.htm> Acesso em 22 de abril de 2019.

11 Disponível em: <https://pt.chabad.org> Acesso em 22 de abril de 2019.

12 Disponível em: <https://pt.chabad.org/library/article cdo/aid/3558909/jewish/As-sete-leisuniversais.htm> Acesso em 22 de abril de 2019.
} 
Essa aliança segundo Gênesis 9.16, é eterna, e por ter sido quebrada, a parte que quebrou o acordo está sujeita às consequências de seus atos: “Toda vez que o arco-íris estiver nas nuvens, olharei para ele e me lembrarei da aliança eterna entre Deus e todos os seres vivos de todas as espécies que vivem na terra". Mas antes de enviar o seu castigo para as nações, por agirem contra a moral da aliança, Deus envia profetas para alertarem as nações. Isso acontece no livro de Amós, onde o profeta declara o juízo sobre os povos, fazendo referência provável aos mandamentos dados a Noé. "Para estarem de acordo com o mandato, todos os povos deveriam respeitar a imagem divina residente em cada ser humano. Mas as nações quebraram esse mandato". Várias atrocidades apresentadas em Amós 1 e 2 mostram que a aliança foi quebrada, como crueldade excessiva, massacres de crianças e mulheres, escravidão e idolatria (CHISHOLM, 2009, p. 355).

A Bíblia mostra como a humanidade acabou descendendo da família de Noé após o Dilúvio. Ao fazer uma aliança com Noé, Deus estabelece algumas leis morais básicas para a boa convivência entre os seres humanos e com Deus. Essas leis morais acabam se tornando uma herança para toda a descendência de Noé. Porém os seres humanos podem decidir seguir ou não está lei moral, mas por possuírem está lei, tornam-se indesculpáveis perante Deus e sujeitos a Ira de Deus, conforme o capítulo 4 deste trabalho.

\section{A IDEIA DA MORAL INTRÍNSECA NO SER HUMANO EM ROMANOS}

Na grande narrativa da Bíblia, as nações parecem sofrer a condenação por causa da negligência do povo de Israel para servir como testemunho. Será que não teriam outra maneira pela qual pudessem conhecer a vontade de Deus e agir de forma que agradasse a Deus?

Como alguém que não crê em Deus busca fazer o bem ao próximo? Será que é por puro egoísmo que faz, apenas para se sentir bem? Ou será que isto mostra que há um Deus que plantou esta semente de moral no coração de cada ser humano?

Paulo trabalha isso nos capítulos iniciais da carta aos Romanos: "Desde que Deus criou o mundo, as suas qualidades invisíveis, isto é, seu poder eterno e sua natureza divina, têm sido vistos claramente. Os seres humanos podem ver tudo isso nas coisas que Deus tem feito e, portanto, eles não têm desculpa nenhuma" (Rm 1.20). Mais adiante o autor aprofunda o tema: "Eles mostram, pela sua maneira de agir, que têm a lei escrita no seu coração. A própria consciência deles mostra que isto é verdade, e os seus pensamentos, que às vezes os acusam e às vezes os defendem mostram isso" ( $\mathrm{Rm} 2.15)$. 
Bruce (1979, p. 67) comenta: "Na vida há uma lei moral segundo a qual os homens são deixados entregues às consequências do curso de ação que eles mesmos escolheram livremente". Segundo o mesmo autor (1979, p. 68) o "objetivo de Paulo é demonstrar que a humanidade toda está moralmente arruinada, incapaz de conseguir um veredito favorável no tribunal do juízo de Deus, em desesperada necessidade de Sua misericórdia e perdão".

Ao olhar para Romanos 1.18-32, Pate (2015, p. 35) escreve:

\begin{abstract}
Os diversos sinônimos de "verdade" e expressões que a descrevem em 1.18-32) [...] se referem tanto ao conceito gentílico estoico (o qual ensinava, segundo a filosofia grega do estoicismo, que a consciência é o critério divino presente em todos os seres humanos) quanto a um conceito judaico, os mandamentos noaicos prescritos por Deus para o mundo depois do dilúvio [...]. A aliança noaica com o mundo reflete a aliança de Deus com Israel e chega a ter pontos em comum com ela, assim como a lei natural tem pontos em comum com a lei mosaica.
\end{abstract}

Mas não só Pate tem este entendimento de Romanos 1.18-32. Keener defende que a filosofia grega, mais especificamente a filosofia estoica afirmava que Deus pode ser visto através da criação, e praticamente em comum consenso esses filósofos afirmavam a existência de um ser divino por trás de toda a criação. Também a mente humana era algo que apontava para Deus segundo os filósofos da época. Os rabinos judeus sabiamente começaram a usar este pensamento para persuadir os pagãos de que o Deus de Israel era o verdadeiro Deus. Assim como Pate (2015, p. 35) fala da aliança noaica como subentendida em Romanos 1.18-32, Keener (2017, p. 510) também aponta nesta direção, mas vai mais além e fala das sete leis que Noé supostamente recebeu de Deus depois do Dilúvio segundo a tradição judaica, como exposto anteriormente.

Segundo Pate (2015, p. 34), nem a lei mosaica nem a noaica e nem a lei natural são capazes de levar à salvação, esta somente é possível através da fé em Jesus Cristo (revelação especial) como Paulo escreve posteriormente ( $\mathrm{Rm} 3.21-31$ ). Porém, há uma questão em debate entre muitos estudiosos, "se é possível conhecer a Deus de forma redentora com base apenas no testemunho da criação e da consciência" (Pate, 2015, p. 38). Neste debate, Pate alerta para a importância de diferenciar teologia natural (favorável à questão) e revelação natural (contrária à questão), principalmente no trecho de Romanos 2, pois Paulo neste trecho enfatiza que a revelação natural não é redentora, apenas condenadora dos pecados.

A linha entre revelação natural ou teologia natural é tênue quando for vista na perspectiva de Lewis (2017), que analisa a moral entre as nações seguindo uma perspectiva semelhante à da tradição judaica das sete leis de Noé. Lewis (2017, p. 55-77) mostra que existe 
uma lei da natureza humana ou lei moral em que todas as civilizações, mesmo as não cristãs, como os antigos babilônicos, gregos, romanos, chineses, povos da África e aborígines da Austrália possuem uma linha comum no que se refere a princípios morais. Assim ele defende os valores universais e a moral absoluta, principalmente nas áreas do altruísmo, da caridade, da justiça e do amor, e crítica duramente argumentos do relativismo. Lewis alerta que é perigoso perder ou questionar os valores morais comuns a todos os seres humanos, e que isto pode leválos a perderem a sua humanidade.

Romanos 1.19,20 é uma das principais passagens no Novo Testamento que trata da revelação natural ou geral de Deus, segundo Stott (2000, p. 79). Stott (2000, p. 80-81) escreve que antropólogos testificam de certa forma o senso moral em todos os seres humanos: "Embora a consciência seja, evidentemente, de alguma forma condicionada à cultura, mesmo assim ela ainda testifica a todos, em todo lugar, que existe uma diferença entre o certo e o errado, e que o mal precisa ser punido".

Um código de conduta, ou Tao como Lewis chama os valores intrínsecos na humanidade, serve para limitar a ação desenfreada dos instintos humanos (LEWIS, 2017, p. 37 38), "parece, portanto que uma ética baseada no instinto dará ao Inovador tudo que ele deseja e irá liberá-lo de tudo que for contrário ao seu desejo". Isso fica bem claro nos versículos subsequentes a Romanos 1.20, onde a perversão humana se torna desenfreada.

Em Romanos 2, a exposição de Paulo segue um rumo semelhante fazendo uma comparação entre gentios e judeus. Stott (2000, p. 96) comenta a respeito de Romanos 2.14 que os gentios não possuem a lei de Moisés como a tinham os judeus, porém em seu íntimo possuem um conhecimento dos padrões da lei. Assim, Paulo afirma que mesmo os gentios fazem institivamente algumas coisas que a lei requer. "Este é um fato observável e comprovável, que os antropólogos veem e comprovam em qualquer lugar que seja” (STOTT, 2000, p. 96).

Segundo Erickson (2013, p. 142) o ser humano faz parte da revelação geral de Deus como ápice da criação. "O caráter de Deus é mais bem percebido nas qualidades morais e espirituais do ser humano. Paulo fala de uma lei escrita no coração das pessoas que não tem a revelação especifica da Lei ( $\mathrm{Rm}$ 2.11-16)”.

Pohl (1997, p. 55) escreve que Paulo não nivela os gentios aos judeus que receberam a lei de Moises, mas afirma que os gentios receberam como bondade de Deus uma lei diferente. Esta lei escrita em seus corações, os ajuda a não se tornarem desumanos de forma forçada, mas podem praticar ações do que é bom, verdadeiro e justo. Na sociedade humana não só 
prevalecem leis econômicas que subjugam todas as pessoas, mas também parâmetros morais. "Porém como a pessoa é capaz de agir de forma humanamente digna, também tem de fazê-lo".

Paulo afirma em Romanos 2.14,15 que os gentios ao agirem conforme a lei sem terem a lei acabam se tornando lei para eles próprios e com isso demonstram que existe uma lei gravada em seus corações. Isso explica, segundo Stott (2000, p. 96), porque nem todos os seres humanos são maus, assassinos, adúlteros ou bandidos. Muitas pessoas fazem o bem, e praticamente seguem os seis últimos dos Dez Mandamentos, ao serem honestos, fiéis aos seus cônjuges, honrarem seus pais e não mentirem. Isto porque quando Deus criou os seres humanos ele os fez pessoas morais e autoconscientes. Hendriksen segue a mesma linha e escreve:

\footnotetext{
Por natureza - ou seja, sem a inclinação ou orientação vinda de algum código escrito, portanto num sentido espontâneo - um gentio às vezes faz certas coisas requeridas pela lei de Deus. Por exemplo, ele é bondoso para com sua esposa e filhos, tem um coração voltado para os pobres, promove a honestidade no governo, revela coragem na luta contra o crime, etc (HENDRIKSEN, 2001, p. 129).
}

Stott (2000, p. 99-100) entende que umas das coisas que Paulo quer dizer em Romanos 2.12-16 é que "a mesma lei moral que Deus revelou nas Escrituras ele também colocou (mesmo que não seja tão legível) na natureza humana. De forma semelhante, Erickson (2013, p. 145) escreve que "sem determinar o conteúdo da revelação interna, Paulo está afirmando que Deus deixou na composição moral humana um testemunho de suas exigências".

De forma geral os autores citados defendem a ideia da moral intrínseca nos seres humanos segundo Paulo em Romanos, tanto como sendo um atributo invisível de Deus (Rm 1.20) ou como uma lei escrita no coração $(\operatorname{Rm} 2.14,15)$. O que diferencia é em relação a sua origem. Alguns autores remetem a moral a uma aliança noaica ou aliança mosaica no caso dos judeus, outros autores a uma aliança na criação diretamente da imagem e semelhança de Deus.

\section{APLICANDO O FUNDAMENTO DE DEUS NAS NAÇÕES}

Com a vinda de Cristo, a imagem de Deus vai sendo recuperada gradativamente nas pessoas através da redenção e com "o crescimento da maturidade cristã". Desta forma "nós vamos nos tornando cada vez mais semelhantes a Cristo na nossa vida e no nosso caráter" (GRUDEM, 1999, p. 366). Gênesis 1.26 e 27 falam dessa imagem e semelhança de Deus nas quais todos os seres humanos são feitos, e isto é "para refletir muitas das qualidades e do caráter 
do próprio Deus. A implicação é que não importa quem sejam, de onde sejam ou o que fizeram ou deixaram de fazer na vida, existe em cada ser humano uma glória e uma importância irredutíveis" (KELLER, 2018, p. 181).

Por outro lado, Nietzsche afirmava que pelo fato de Deus não existir, também não podem existir fatos morais. Nietzsche nesta afirmação liga os valores morais diretamente a um Deus superior. A questão está baseada no simples fato de Deus existir ou não. Ao se afirmar que fatos morais existem, e que fatos morais são reflexo de um Deus, logo Deus existe. O contrário nesta lógica também seria verdade. O fato é praticamente inquestionável, valores ou fatos morais estão atrelados a um Deus (KELLER, 2018, p. 238-243). O argumento moral combina tanto evidências racionais como pessoas. "Se existe um Deus de bondade e verdade, e estabelecemos um relacionamento com ele, essa bondade e verdade não deveriam se manifestar também na vida humana?" (KELLER, 2018, p. 242).

Dostoiewzki escreveu que sem Deus tudo seria permitido e seria possível fazer qualquer coisa, muitos usam isto como justificativa para afirmar que pessoas não crentes em Deus são menos boas ou morais do que aquelas que creem. Mas isso não é uma verdade (KELLER, 2018, p. 224). Keller continua desenvolvendo este ponto e afirma:

\footnotetext{
Qualquer um que tente afirmar que os ateus são, como indivíduos ou no todo, menos morais do que outros deparará com o senso comum e a experiencia. [...] o Novo Testamento ensina, de um lado, que todas as pessoas, independentemente da crença, são criadas por Deus com uma consciência moral (Rm 2.14,15). Por outro lado, o mesmo texto diz que todos, inclusive os crentes, são pecadores imperfeitos (Rm 3.912). Assim, considerando as premissas até mesmo da própria doutrina cristã, é errado declarar ou dar a entender que não se pode ser bom sem Deus (KELLER, 2018, p. 224-225).
}

Burke vai ao encontro da linha de Keller e escreve que ao estudar as mais diversas religiões do mundo, chegou à conclusão que todas dizem algo semelhante em relação ao que é certo e ao que é errado, como se existisse uma bússola moral em cada pessoa. "É misterioso a semelhança do código moral de todas as grandes religiões, quase como se essa compreensão inata do certo e do errado viesse de dentro". De fato, é o que a Bíblia ensina em Romanos 2.14,15 (BURKE, 2006, p. 162). Isto se assemelha muito com as ideias de Lewis em abolição do homem e com as leis de Noé descritas acima.

Como isso funciona na prática, Don Richardson mostra em seu livro "Fator Melquisedeque". Nele relata experiências de missionários, que ao chegarem entre os mais diversos povos da terra, encontraram pontos de contato entre a cultura do povo e o evangelho. Quando conseguiram usar estes pontos de contato como um alicerce para o evangelho, a 
mensagem conseguiu alcançar estes povos de modo surpreendente, vindo a se converterem em grandes proporções. Richardson (2008, p. 65) escreve que "nenhuma outra mensagem da terra já possui um alicerce lançado para si mesmo nos sistemas de fé de milhares de sociedades humanas completamente diversas". De certa forma isto mostra que Deus implantou algo nos seres humanos desde a criação, uma espécie de lei escrita no coração e atributo invisível de Deus conforme Romanos 1 e 2 .

Porém, ao invés de ver estes pontos de contato nas outras nações como algo bom e útil, "instigou-se a ver as semelhanças com o cristianismo em outras culturas como barreiras ao evangelho, em vez de umbrais com inscrição "bem-vindos!” (RICHARDSON, 2008, p. 65).

Lewis em "Cristianismo puro e simples" defende uma lei natural de Deus destacando dois pontos:

\footnotetext{
Primeiro, que os seres humanos, de todos os cantos do mundo, têm essa ideia curiosa de que devem se comportar de determinada forma e não conseguem realmente não fazê-lo; em segundo lugar, os indivíduos, na verdade, não se comportam dessa forma. Eles conhecem a Lei Moral, mas a transgridem. Esses dois fatores são a base de todo o pensamento claro sobre nós e o universo onde vivemos (LEWIS, 2017, p. 35).
}

Keller propõe no livro "Pregação - comunicando a fé na era do ceticismo", que a pregação não pode nem ser alheia a cultura que está inserida e ao mesmo tempo não pode deixar de confrontá-la. Keller (2017, p. 119,120) cita o exemplo bíblico do evangelho de João, que ao usar a palavra logos para atribuir a Jesus Cristo "o poder e o sentido por trás do cosmos" está construindo em cima de algo já existente na cultura grega. "João não apenas confrontou a cultura, tampouco apenas adaptou-se a ela". Paulo em seus discursos também usa "pontos de contato" quando conversa com os diferentes grupos e culturas. Ele não apenas confronta seus ouvintes e busca contradizê-los, mas raciocina com eles para buscar convencê-los. "Paulo pega algumas das crenças corretas de seus ouvintes e as usa para criticar suas crenças erradas à luz da Escritura" (KELLER, 2017, p. 121-122).

Assim Paulo busca pontos de contato com seus ouvintes para trazer o evangelho: "Ao endossar percepções por meio das quais podia chegar a elas, ao adotar conceitos e modos de raciocínio que elas pudessem compreender, Paulo não está simplesmente querendo refutá-los, mas também respeitá-los” (KELLER, 2017, p. 122). Paulo constrói seus argumentos a partir de pontos já existentes para os seus ouvintes a fim de estabelecer o diálogo e chegar com a mensagem do evangelho, o que fica evidente na narrativa de Atos e na carta aos Romanos. 
Hiebert propõe que ao adicionar elementos a uma cosmovisão, sem destruir elementos preexistentes, acaba dando significado diferente a estes elementos e transforma a cosmovisão inicial. Compreender a estrutura em como funciona a cosmovisão, ajuda a levar o evangelho e uma possível conversão da pessoa. Porém muitos enxergam essa construção do evangelho a partir de elementos preexistentes, como uma forma de contaminação da nova cosmovisão. Mas Hiebert mostra que "é possível usar elementos tradicionais na elaboração de respostas cristãs em contextos culturais específicos, entretanto eles precisam evidentemente receber novos significados" (HIEBERT, 2016, p. 347-348).

Segundo McGrath (2008, p. 19) a apologética cristã deve buscar construir pontes entre as pessoas e o evangelho, através de pontos de contato que variam de cultura para cultura e de individuo para indivíduo. Porém "Deus já lançou os fundamentos dessas pontes no mundo e no coração humano; nossa responsabilidade consiste em construir sobre esses fundamentos, fazendo as ligações necessárias". Como Deus criou o mundo, não é de se surpreender que a própria criação carregue sinais que testemunhem a respeito Dele, como a moral da humanidade. Isso Paulo mostra em Romanos 1 e 2, de que existe um ponto de contato já estabelecido por Deus na criação, e assim se isto for verdade, não é preciso "estabelecer os fundamentos do conhecimento cristão de Deus", e pode-se construir a partir destes pontos estabelecidos por Deus na criação, como a moral. (McGRATH, 2008, p. 20).

Como o próprio Paulo deixa claro na carta aos Romanos nos capítulos 1 a 3, estes sinais de Deus, atributos e lei escrita no coração, apenas apontam para o criador, mas não são suficientes para trazer a salvação para a humanidade. McGrath explica isso da seguinte forma:

\footnotetext{
Ponto de contato é um ponto de apoio dado por Deus para a auto revelação divina. É um catalisador, mas não um substituto da revelação divina. É como uma linha de batedores de um exército, que prepara o terreno para a força maior que a segue. É semelhante ao momento que precede o raio, em que se estabelece uma via de condução entre a terra e o céu, de modo que a quantidade massiva de energia do relâmpago possa ser descarregada por completo na terra que a espera. Deus dá de si mesmo no ato da revelação e, em certo sentido, ele já preparou o terreno para essa doação, não para antecipá-lo, nem para dispensá-la, mas simplesmente para torná-la mais eficaz quando finalmente se der (McGRATH, 2008, p. 22).
}

Para estabelecer este ponto de contato, é necessário primeiro identificá-lo nas pessoas, pois varia conforme a cultura e o indivíduo, na moral uma destas pistas pode estar visível para aquele que busca construir estas pontes. Para isso, McGrath (2008, p. 59-66) afirma que é muito importante primeiro conhecer o ouvinte e a sua cosmovisão, o que ele pensa e sente. Assim o diálogo ou apresentação do evangelho acaba se tornando uma resposta aos anseios 
do ouvinte em uma forma e linguagem que ele compreenda. Para fazer isto é necessário tirar da mensagem tudo que seja cultural do comunicador e levar a mensagem em uma linguagem que o ouvinte esteja familiarizado. Esta era a estratégia de Jesus, que ao contar seus ensinamentos em forma de parábolas estava introduzindo conceitos novos aos seus ouvintes, com base em histórias e questões culturais conhecidas por eles. Paulo faz o mesmo em suas cartas e no discurso do Areópago em Atos 17 (McGRATH, 2008, p. 59-66).

Assim, pode-se procurar estes "pontos de receptividade" ou acessibilidade em todas as pessoas. McGrath (2008, p.91) mostra que a moral é uma ponte para levar o evangelho aos seres humanos:

\footnotetext{
Os seres humanos são criados a imagem de Deus. Portanto, é de esperar que as ideias divinas de justiça e equidade estejam, de algum modo, implantadas em nossa natureza. Assim como a criação traz a marca do seu criador, também a natureza humana traz consigo o selo moral da divindade. Nossas ideias sobre justiça não são arbitrárias; elas encontram eco na natureza do próprio Deus (McGRATH, 2008, p. 91).
}

Desta forma o papel dos cristãos é dar um sentido maior para aquelas coisas que já podem ser vistas em todas as nações por meio das coisas naturais dos seres humanos, como a moral. "A tradição cristã possibilita "ver" ou "contemplar" a natureza de tal maneira que sua verdade, beleza e bondade, que de outra maneira seriam obscuras ou ambíguas, possam ser percebidas”. Uma teologia natural correta, fundamentada na teologia cristã, possibilita assim dar esta percepção diferente sobre a natureza para as nações. Essa percepção de ver a natureza, incluindo a moral, de forma diferente acaba não ficando somente na esfera racional, mas também na imaginação e emoção humana. Assim as "visões racionais, estéticas e morais" acabam ganhando um significado maior se forem influenciadas pela verdade bíblica de Jesus, se forem colocadas em contato com mundo, no qual todo cristão é chamado para agir. (McGRATH, 2019, p. 298-299)

Assim cabe a igreja buscar os pontos de receptividade para levar o evangelho de uma forma clara e contextualizada, a moral é um destes pontos que ao serem identificados podem ser usados para construir uma apresentação do evangelho e dar sentido a algo já existente na cultura da pessoa. Desta forma a igreja será a luz do mundo e o sal da terra, conforme Mateus 5.16: "Assim também a luz de vocês deve brilhar para que os outros vejam as coisas boas que vocês fazem e louvem o Pai de vocês, que está no céu". 


\section{CONCLUSÃO}

No estudo da teologia natural e dos fundamentos de Deus para as nações, alguns pontos chaves parecem sempre entrar em pauta: A criação ordenada de Deus, a criação do homem à Imagem e Semelhança de Deus, a Queda, revelação geral, a revelação especial em Jesus, a carta de Paulo aos Romanos e o discurso de Paulo em Atenas de Atos 17. Estes temas apontam para estruturas pré-existentes, pontos de contato, atributos invisíveis ou uma lei escrita no coração dentro das nações e de cada ser humano individual. Dentre estes elementos que apontam para o Criador, a moral pode também ser compreendida como algo que Deus plantou no coração do ser humano.

Na Bíblia o maior exemplo de comunicação usando elementos conhecidos pelo ouvinte foi o próprio Senhor Jesus, que ao encarnar como ser humano se identificou completamente com a humanidade. Além disso, ao usar histórias conhecidas pelas pessoas da época ele passava uma nova mensagem aos ouvintes e uma nova moral. Este é um exemplo que deve ser copiado pela Igreja para levar o evangelho para aqueles que ainda não aceitaram a sua mensagem. Mas de forma geral, Jesus pregou para pessoas do seu próprio contexto, se Jesus tivesse mais tarde pregado para outros povos provavelmente usaria a forma como Paulo fala aos gregos em Atos 17, na qual o apóstolo usa elementos conhecidos dos ouvintes para construir a sua defesa do evangelho. Paulo encontra um ponto de contato para levar a mensagem, elogia os ouvintes pelo que eles têm de positivos, mas não deixa de confrontar com as boas novas.

Assim, a forma mais correta de abordar alguém e estabelecer um diálogo é primeiro identificar pontos de contato com o evangelho que a pessoa já possui. Um destes pontos de contato podem ser atitudes morais da pessoa, como atos de altruísmo, caridade, justiça e amor. Pois a Bíblia mostra que estes são essenciais no ser humano, e vem da própria imagem de Deus. Embora que o pecado distorça estas qualidades, elas ainda estão presentes no ser humano. Assim elas podem ser usadas como estruturas pré-existentes nas pessoas para trazer a mensagem do evangelho. Em segundo lugar a atitude de Paulo em Atos 17 mostra que depois de identificado o ponto de contato, Paulo respeita seu ouvinte com aquilo que este demonstra de bom. Esta atitude é um exemplo para aqueles que se acham superiores aos não crentes por possuírem a mensagem do evangelho, e os tratam como inferiores, pois os não crentes podem fazer coisas boas e o fazem muitas vezes melhor do que aqueles que se dizem cristãos.

Porém no terceiro momento de Paulo ele não deixa de confrontar seus ouvintes com a verdade do evangelho. Apesar dos pontos de contato apontarem para Deus, eles não são suficientes para a salvação, como Paulo deixa claro na carta aos Romanos 3.23,24: "Todos 
pecaram e estão afastados da presença gloriosa de Deus. Mas, pela sua graça e sem exigir nada, Deus aceita todos por meio de Cristo Jesus, que os salva.” E por isso a revelação geral não é suficiente para redimir a humanidade, isto é apenas através da revelação especial por meio de Jesus Cristo.

Estruturas pré-existentes em cada ser humano ajudam a apontar para Deus, e por isto os pontos de contato podem e devem ser usados para trazer a mensagem do evangelho. Estes elementos podem ser usados para dar sentido ao todo da cosmovisão das pessoas e dar um rumo novo para suas crenças. Deus deixou as suas pegadas visíveis para a humanidade se lembrar do propósito inicial da sua criação e por meio da moral ela reflete atributos de Deus em sua essência e em seu coração.

\section{REFERÊNCIAS}

BARTHOLOMEW, Craig G.; GOHEEN, Michael W. Drama das Escrituras: Encontrando o nosso lugar na história bíblica. São Paulo: Vida Nova, 2017.

BÍBLIA SAGRADA - Nova Tradução na Linguagem de Hoje. São Paulo: Sociedade Bíblica do Brasil, 2015.

BÍBLIA Sagrada, Nova Versão Internacional - Bíblia de Estudos Arqueológica. São Paulo: Vida, 2013.

BRITANNICA, The Editors Of Encyclopaedia. Lactantius: Christian apologist. 2009. Disponível em: <https://www.britannica.com/biography/Lactantius>. Acesso em: 22 nov. 2019.

BRUCE, F. F. Romanos: introdução e comentário. São Paulo: Vida Nova, 1979.

BURKE, John. Proibido a entrada de pessoas perfeitas: Um chamado a tolerância na igreja. São Paulo: Vida, 2006.

CHABAD. As sete leis de Noé. 2018. Disponível em: https://pt.chabad.org/library/article_cdo/aid/3312135/jewish/As-Sete-Leis-de-No.htm. Acesso em: 22/04/ 2019.

CHABAD. As sete leis universais. 2018. Disponível em: https://pt.chabad.org/library/article_cdo/aid/3558909/jewish/As-sete-leis-universais.htm. Acesso em: 22/04/ 2019.

CHISHOLM Jr, R. B. Amós. In: ALEXANDER, T. Desmond; ROSNER, Brian S. (Orgs.). Novo Dicionário de Teologia Bíblica. São Paulo: Vida, 2009, p. 353-357.

ERICKSON, Millard J.. Teologia sistemática. São Paulo: Vida Nova, 2015.

GRUDEM, Wayne. Teologia sistemática. São Paulo: Vida Nova, 1999. 
HENDRIKSEN, William. Comentário do Novo Testamento: Romanos. São Paulo: Cultura Cristã, 2001.

HIEBERT, Paul G. Transformando cosmovisões: uma análise antropológica de como as pessoas mudam. São Paulo: Vida Nova, 2016.

HUNTEMANN, Georg. Der verlorene Maßstab: Gottes Gebot im Chaos dieser Zeit. LahrDingligen - Lahr-Dinglingen, Germany: Liebenzeller Mission/Telos, 1983.

KEENER, Craig S.. Comentário Histórico-Cultural da Bíblia: Novo Testamento. São Paulo: Vida Nova, 2017.

KELLER, Timothy. Pregação: comunicando a fé na era do ceticismo. São Paulo: Vida Nova, 2017.

KELLER, Timothy. Deus na era secular: como céticos podem encontrar sentido no cristianismo. São Paulo: Vida Nova, 2018.

LEWIS, C. S. A abolição do homem. Rio de Janeiro: Thomas Nelson Brasil, 2017.

LEWIS, C. S. Cristianismo puro e simples. Rio de Janeiro: Thomas Nelson Brasil, 2017.

MCGRATH, Alister. Teologia sistemática, histórica e filosófica. São Paulo: Shedd Publicações, 2005.

MCGRATH, Alister. Apologética cristã no século XXI: Ciência e Arte com integridade. São Paulo: Vida, 2008.

MCGRATH, Alister. Teologia Natural: Uma nova abordagem. São Paulo: Vida Nova, 2019. PATE, C. Marvin. Romanos: Séria Comentário Expositivo. São Paulo: Vida Nova, 2015. POHL, Adolf. Carta aos Romanos: Comentário Esperança. Curitiba: Esperança, 1999.

STOTT, John R. W. A mensagem de Romanos - São Paulo: ABU, 2000.

STURZ, Richard J. Teologia Sistemática. São Paulo: Vida Nova, 2012.

RAMBO, Lewis R.; FARHADIAN, Charles E. (Ed.). The Oxford Handbook of religious conversion. New York: Oxford University Press, 2014. (p. 589-591).

RICHARDSON, Don. Fator Melquisedeque: o testemunho de Deus nas culturas por todo o mundo. 3. ed. São Paulo: Vida Nova, 2008. 